Article

\title{
Industrial Infrastructure: Translocal Planning for Global Production in Ethiopia and Argentina
}

\author{
Elke Beyer, Lucas-Andrés Elsner * , Anke Hagemann and Philipp Misselwitz \\ Habitat Unit, Institute of Architecture, Technical University of Berlin, Germany; E-Mails: e.beyer@tu-berlin.de (E.B.), \\ I.elsner@tu-berlin.de (L.-A.E.), anke.hagemann@tu-berlin.de (A.H.), misselwitz@tu-berlin.de (P.M.) \\ * Corresponding author
}

Submitted: 14 March 2021 | Accepted: 22 June 2021 | Published: 23 September 2021

\begin{abstract}
Current development and re-development of industrial areas cannot be adequately understood without taking into account the organisational structures and logistics of commodity production on a planetary scale. Global production networks contribute not only to the reconfiguration of urban spatial and economic structures in many places, but they also give rise to novel transnational actor constellations, thus reconfiguring planning processes. This article explores such constellations and their urban outcomes by investigating two current cases of industrial development linked with multilateral transportinfrastructure provisioning in Ethiopia and Argentina. In both cases, international partners are involved, in particular with stakeholders based in China playing significant roles. In Mekelle, Ethiopia, we focus on the establishment of a commodity hub through the implementation of new industry parks for global garment production and road and rail connections to international seaports. In the Rosario metropolitan area in Argentina, major cargo rail and port facilities are under development to expand the country's most important ports for soybean export. By mapping the physical architectures of the industrial and infrastructure complexes and their urban contexts and tracing the translocal actor constellations involved in infrastructure provisioning and operation, we analyse the spatial impacts of the projects as well as the related implications for planning governance. The article contributes to emergent scholarship and theorisations of urban infrastructure and global production networks, as well as policy mobility and the transnational constitution of planning knowledge and practices.
\end{abstract}

\section{Keywords}

Argentina; China; Ethiopia; global production networks; infrastructure-led development; transnational urban spaces

\section{Issue}

This article is part of the issue "Future Commercial and Industrial Areas" edited by Angela Million (TU Berlin, Germany) and Felix Bentlin (TU Berlin, Germany).

(C) 2021 by the authors; licensee Cogitatio (Lisbon, Portugal). This article is licensed under a Creative Commons Attribution 4.0 International License (CC BY).

\section{Introduction}

The belief that integration in global production networks and seamless flows of goods is a prerequisite of successful development and poverty alleviation in the Global South still guides powerful international institutions, such as the World Bank, and national policy agendas. The continuing influence of this paradigm is reflected in the many large-scale infrastructure projects in the Global South related to manufacturing and resource extraction aimed at integrating urban regions in glob- alised production systems and promoted by a global "growth coalition" comprised of development banks, governments, multilateral institutions, transnational corporations, and consultancies (Schindler \& Kanai, 2019). These include new powerful actors such as state-owned enterprises and banks from China, as well as numerous firms from other Asian countries, as major drivers of a new "South-South" cooperation in planning, engineering, and manufacturing (Anand et al., 2018). China's Belt and Road Initiative can be regarded as largest among a variety of multilateral and bilateral initiatives 
of infrastructure-led development (Liu et al., 2020). In Ethiopia, for example, building physical infrastructures for global garment manufacturing, such as industrial parks and related logistics facilities to attract global fashion brands and their transnational suppliers, became a key national development priority in the last 10 years (Ethiopia National Planning Commission, 2016; United Nations Development Programme Ethiopia, 2017). However, implementation has only been made possible through foreign capital and construction firms, mainly from China (Jalles d'Orey \& Prizzon, 2017; World Bank, 2017), which has complemented national investments. In Argentina, the upgrading and expansion of transport infrastructures for global soy production and distribution is implemented by state agencies in close cooperation with firms and financing from China (Ministerio de Transporte, 2017a).

Partnerships between national governments and Chinese companies to develop critical infrastructure projects have triggered controversial debates in policy and research. They often fall under the umbrella of the Belt and Road Initiative, an agenda that has been described as deliberately fuzzy with regard to its official goals, geographical scope, and means of implementation (Narins \& Agnew, 2020). Researchers have questioned the long-term economic effects and sustainability of infrastructure-led development in general (Schindler \& Kanai, 2019), or problematised the lack of involvement of local municipal planning in implementing such projects (e.g., Beyer et al., in press; Goodfellow \& Huang, 2021; Kanai \& Schindler, 2019). Some of these authors have pointed towards the way such infrastructural constellations enable the exploitation of spatial differences within global production networks and, thus, contribute to uneven development (Arboleda, 2016; Kanai \& Schindler, 2019). Although their extensive impacts on urbanisation dynamics are undisputed, a comprehensive and critical urban assessment of translocal infrastructure initiatives is largely missing, particularly in relation to global production networks. In fact, unravelling the conflicts and fault lines at the interface of infrastructure provision and urban development is particularly relevant given the multiple sustainability challenges in "industrialising" countries, augmented by the Covid-19-related crisis, and the size of the financial commitment already made by national and local governments in relation to transnational infrastructure investments. To answer the questions raised, more solidly grounded case studies are needed to "demystify" (Liu et al., 2020) infrastructure development with Chinese involvement and exploring its varying contours and impacts. Such case studies ought to shed light on the local and spatial development impacts of transnational infrastructure provisioning and to untangle multilateral negotiation processes between the involved actors, such as local government agencies, local communities, development agencies, and a variety of Chinese state-owned enterprises (Goodfellow \& Huang, 2021; Liu et al., 2020).
Addressing this gap, this article takes a closer look at the interrelations between industrial infrastructure provisioning and global networks of production and explores their repercussions in terms of urban development and planning governance. Two case studies of industrial areas in Mekelle, Ethiopia, and Rosario, Argentina, will be discussed as crystallisation points of wider transnational networks of production, logistics, and on-going infrastructure development. The article considers manufacturing and processing facilities as integral components of infrastructural arrangements facilitating global commodity circulation. Our analysis is guided by an understanding of infrastructures as "socio-technical apparatuses and material artifacts that structure, enable, and govern circulation" (Burchardt \& Höhne, 2015, p. 3). Such a holistic view on the provisioning of industrial infrastructures links physical-material aspects to questions of planning, construction, operation, and maintenance (Leigh Star, 1999). Our findings build on the combination of the spatial analysis of emerging industry and infrastructure complexes in specific urban contexts and a transnational and comparative perspective on their provisioning, i.e., the ways they are planned, constructed, and negotiated through novel transnational actor constellations, including local actors and stakeholders from global production networks. Our approach integrates recent scholarship and theorisations around urban infrastructure, global production networks, as well as the transnational constitution and circulation of planning knowledge and practices.

\section{Transnational Research Perspectives on Infrastructure Provisioning}

Interdisciplinary debates on infrastructures and commodity flows in cities have gained considerable momentum in recent years (for a more extensive review of the literature see Beyer et al., 2020). Scholars of architecture and planning, as well as urban geography, have developed relational perspectives on how urban fabric is produced and organised through infrastructures, and how infrastructural networks spatialise socioeconomic power relations (e.g., Graham \& Marvin, 2001; McFarlane \& Rutherford, 2008). Easterling (2014) and others have begun to show how infrastructure provisioning contributes to the emergence of new spatial and political configurations, for example the physical enclaves of special economic zones or segregated corridors, producing landscapes of "splintering urbanism" (Enns, 2018; Graham \& Marvin, 2001; Kanai \& Schindler, 2019). For their part, architectural scholars have developed innovative methods for analysis and visual representation of logistical infrastructure systems, their physical form, and urban impact (Hein, 2018; LeCavalier, 2016; Lyster, 2016). Yet, following Lin (2019), we contend that particularly the interrelations between transnational production relations and urban infrastructures remain understudied. Here, the global production 
networks' heuristic approach, rooted in economic geography, offers particularly suitable entry points. It allows for an identification of the transnational actor constellations orchestrated by global "lead firms" within the industry and include actors on various scales of governance. Global production networks' scholarship and related approaches have generated instructive empirical analyses of global economic networks, including fundamental studies on the clothing and soy industries (Bair \& Gereffi, 2001; for specific treatments of our case study regions see Dobelmann, 2012; Staritz et al., 2016). Furthermore, the approach draws attention to how network integration can foster regional development (Coe \& Yeung, 2015; Henderson et al., 2002) and how it contributes to uneven geographies (Werner, 2016). The notion of "strategic coupling" is particularly helpful to conceptualise the nexus between the provisioning of infrastructures and the integration of a place in global production relations. It allows us to grasp how a match between a region's assets and the strategic needs of global lead firms is created in order to plug a region into global production networks. Jacobs and Lagendijk (2014, p. 51) understand "[t]he provision and deployment of key infrastructure...[as] one of the primary vehicles through which to facilitate the insertion of a place into a global production network and, thus, to accomplish strategic coupling." Also, recent research has stressed the centrality of infrastructures for coupling and de-coupling processes (Gao et al., 2017; Scholvin et al., 2019) and demonstrated the impacts the provision of infrastructure at one place can have on other network nodes (Breul et al., 2019).

At the same time, various strands of urban and geographical research have demonstrated the transnational interrelatedness of urban development. Urban research debates on the mobility and transnational constitution of planning knowledge and practices (Grubbauer, 2015; Parnreiter, 2015), as well as urban policies (McCann \& Ward, 2012; Peck \& Theodore, 2010), provide useful concepts and methodologies by which to explore the transnational processes and actors involved in the planning and provisioning of (urban) infrastructure (Harris, 2013; Kanai \& Schindler, 2019; Rode et al., 2020; Wiig \& Silver, 2019). Investigating the development of industrial and infrastructural urban spaces through the respective transnational flows and relations also speaks to discussions on "worlding" urban research (Roy, 2009). The concept of "worlding" brings to the fore the importance of contextualising urban development through widening the focus to the various translocal networks of knowledge, capital, commodities, and labour that cities are embedded in. However, scholars such as Söderström (2014) criticise such concepts as too abstract to capture "how connections and flows depend on and create material places" (pp. 171-172). Drawing on Söderstrom, we contend that focussing on the relational constitution of the particular built forms that enable transnational connections can contribute to closing this gap and direct long overdue attention to the globally interconnected nature of infrastructures for commodity production and circulation.

\section{A Relational, Multi-Scalar Approach to Interrogate the Provisioning of Infrastructures for Global Production Systems}

Our approach combines multi-scalar spatial analysis of emerging industry and infrastructure complexes in their specific urban settings with a relational, translocal perspective on their provisioning by translocal actor constellations, including stakeholders from global production networks and government authorities in charge of economic and spatial planning on different scales, as illustrated in Figure 1.

Spatial analysis encompasses three major analytical scales:

1. Buildings and their immediate surroundings, capturing the footprint and specific characteristics of built forms that facilitate the processing and movement of commodities;

2. Urban region or larger urban contexts of the industry-infrastructure complexes defined as "commodity hubs" (Giraudo, 2015), encompassing relevant urban planning schemes, spatial impacts on surroundings such as land use changes, land consumption, and environmental, social, and economic costs and benefits;

3. Translocal flows and infrastructure networks: On a larger scale, the commodity hubs are contextualized within national and transnational infrastructural networks such as commodity transportation and logistics.

Complementing the spatial analysis, we identify key actors involved in the design, implementation, and operation of the respective industrial infrastructure in three major fields: infrastructure provision, spatial planning, and global production. Tracing entanglements and overlaps between these fields allows us to capture the translocal constellations of actors involved in industrial infrastructure provisioning, to identify protagonists of "strategic coupling" with global production networks, and, most importantly, to chart power asymmetries and scalar mismatches posing specific challenges to urban planning.

The article draws on ongoing research, including fieldwork conducted between 2017 and 2019 in Ethiopia (Addis Ababa and Mekelle) and Argentina (Buenos Aires and Rosario), with the goal to trace how the processes, multi-scalar constellations, and negotiations of infrastructure provisioning correlate with physical urban transformations. Our findings are based on the triangulation of different qualitative methods of gathering empirical data, drawing on a pool of methods as suggested by McCann and Ward (2012) for tracing the diffusion of urban policies 


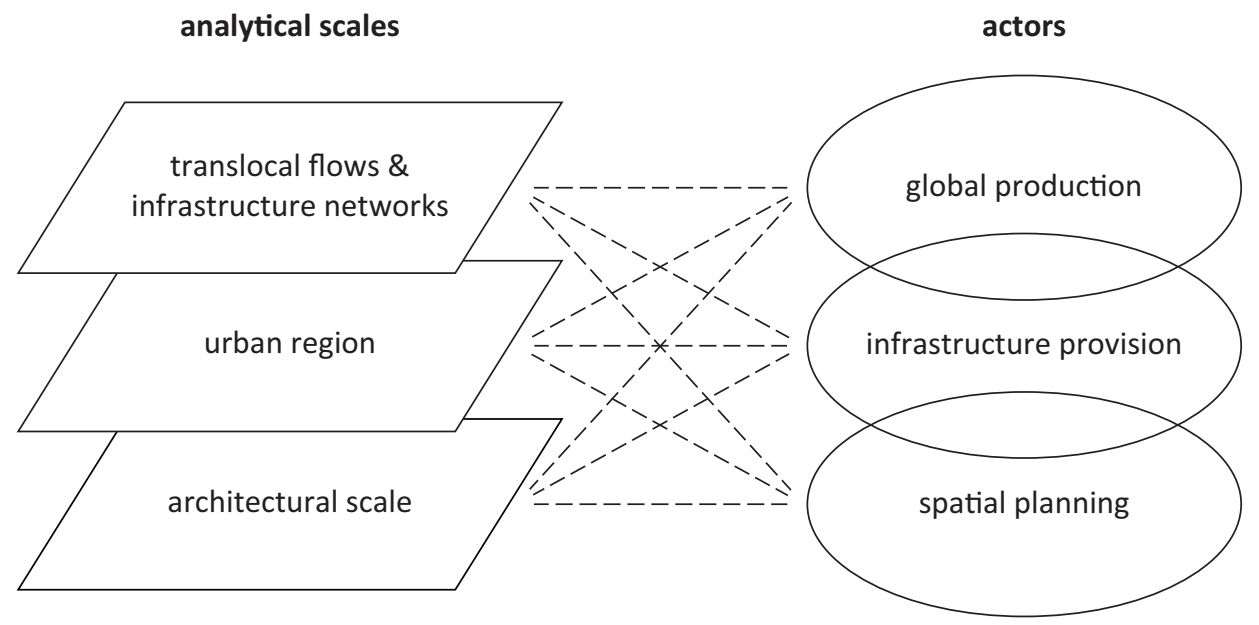

Figure 1. Analytical framework.

through interviews, maps, documents, and media analysis, as well as non-participant observation.

The analytical maps were prepared on the basis of existing maps and satellite images, as well as planning and design documents such as master plans, land-use plans and building plans, policy documents, and reports, all validated through on-site observations documented with photographs and drawings. At all locations, semistructured expert interviews (Gläser \& Laudel, 2010) were conducted with representatives of urban and transportation planning bodies on various scales: infrastructure providers and operators, companies involved in global commodity production and circulation, domestic and international development agencies, as well as other academic researchers. In total, we conducted 46 interviews (36 in or related to Ethiopia, 10 in Argentina). These were complemented by non-participant observation at trade fairs and conferences promoting industrial development, as well as evaluation of policy documents issued by state institutions, international organisations and NGOs, industry reports, technical reports, and planning and legal documents.

\section{New Clothing Industry Parks in Mekelle: The Making of a Commodity Hub in Ethiopia}

Mekelle city, the capital of the Tigray Regional State in northern Ethiopia, is an instructive case to study how transnational actors and stakeholders in globalised commodity production become significant players in negotiating and physically shaping urban space. At the same time, infrastructure provisioning for manufacturing and global circulation of commodities has become a primary goal of government agencies, leading to new spatial interventions. In the case of Mekelle, the potentially short life and fragility of globalised production arrangements also come to the fore-particularly in light of the violent conflicts between Ethiopia's federal government and the Tigray Regional State that have flared up since autumn 2020. The outcome of these conflicts is highly uncertain at the time of writing and will be critical for the full implementation and future use of infrastructure already in place and in the making.

\subsection{Spatial Impacts of Industry Zone Construction}

With a population of approximately 500,000 within its current municipal boundaries, but about 1.5 million people living in a $50 \mathrm{~km}$ radius, Mekelle is an important secondary city in Ethiopia and a regional centre for administration, industry, business, and education. The city has been steadily growing over the past decades due to migration from rural areas and municipal boundaries were successively expanded (Mekelle University, 2014; Negese et al., 2017; Teka, 2020). In late 2018, when our field visits were conducted, there were four large monofunctional export-oriented industry zones under construction on greenfield sites on the periphery of the city (see Figure 2), all specialising in garment making and with the goal to employ more than 10,000 workers each. Apart from the state-run flagship project, the Mekelle Industry Park (MIP), three large clothing production complexes were being developed by private investors from India, the United Arab Emirates, Bangladesh, and Italy. In addition to its own integrated jeans factory, one of these complexes was set to become a 170 ha, privately run industry park for other companies. Each of the projects was facilitated through significant involvement of various stakeholders at the national scale, such as the Ethiopian Investment Commission, the Development Bank of Ethiopia, and the Industrial Parks Development Corporation (IPDC), as well as transnational actors in the garment industry (global brands and their supplier networks) and in the fields of development cooperation, consultancy, and construction engineering (see Figure 2). As the map shows, the sites are situated in urban fringe areas which are divided, in very broad swathes, into zones for industrial, logistics, or uniform state-led residential developments (plus higher education campuses). Current planning seeks to connect the industrial 


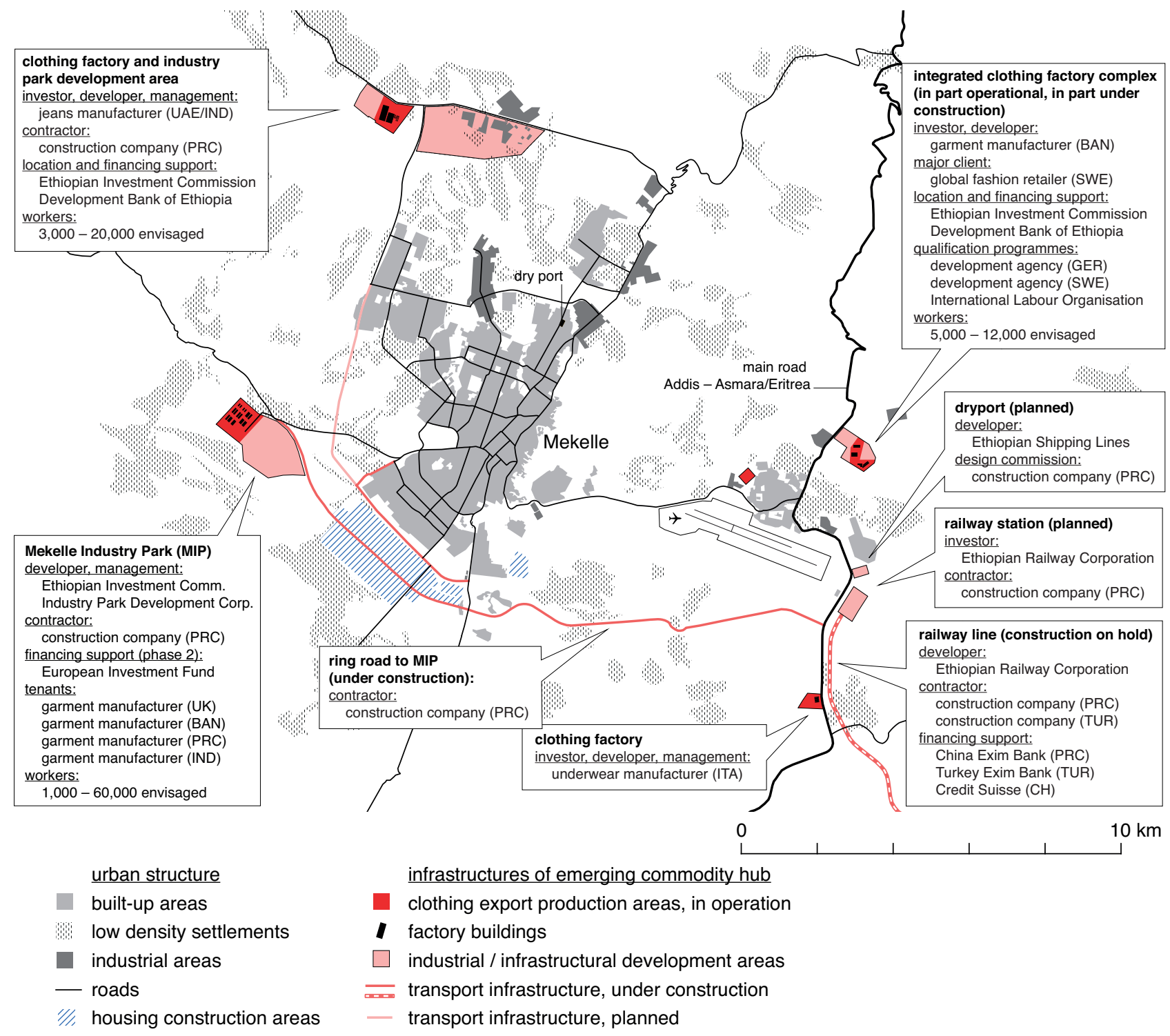

Figure 2. Industry and infrastructure projects for export production in Mekelle and involved actors (2018). Sources: Authors based on Google Maps, OpenStreetMap, IPDC (2015), and authors' interviews.

development sites - which had only recently been incorporated into the administrative territory of the city-to the main overland transport arteries by the construction of four-lane roads circumventing the city.

For example, at MIP on the south-western fringe of the city, the regional government designated an area of 1,000 ha for textile and garment production. In the first development phase, it covers an area of 75 ha and encompassed the following building works: 15 turn-key sheds of two sizes; offices for customs, tax issues, etc.; and road and engineering networks, including a wastewater treatment plant (see Figures 3 and 4). The Ethiopian government financed the construction, executed on a design-and-build contract by the Chinese Communications Construction Company (CCCC) within nine months after winning the tender. The monotonous spatial layout of the industry park contrasts sharply with the peri-urban context of agriculture and village structures. By 2018, the park, managed jointly by the Ethiopian Investment Commission and the IPDC, had been inaugurated, and sewing companies from China, India, Bangladesh, and the UK were among the first tenants. An additional area of 163 ha was announced as ready for the second construction phase, to be financed through a \$500-million contract with the European Investment Bank. At the time of writing, however, operations in the park had been temporarily suspended due to the military conflicts of late 2020 .

The immediate spatial impacts resulting from export-oriented industrial infrastructure development in Mekelle are significant. Not only do the large industrial sites and dual carriageways reconfigure the arid landscape of seasonal pastureland dramatically, dissecting intricate settlement patterns of small farmsteads in traditional stone masonry, they also divide the emerging residential estates south-west of the city 


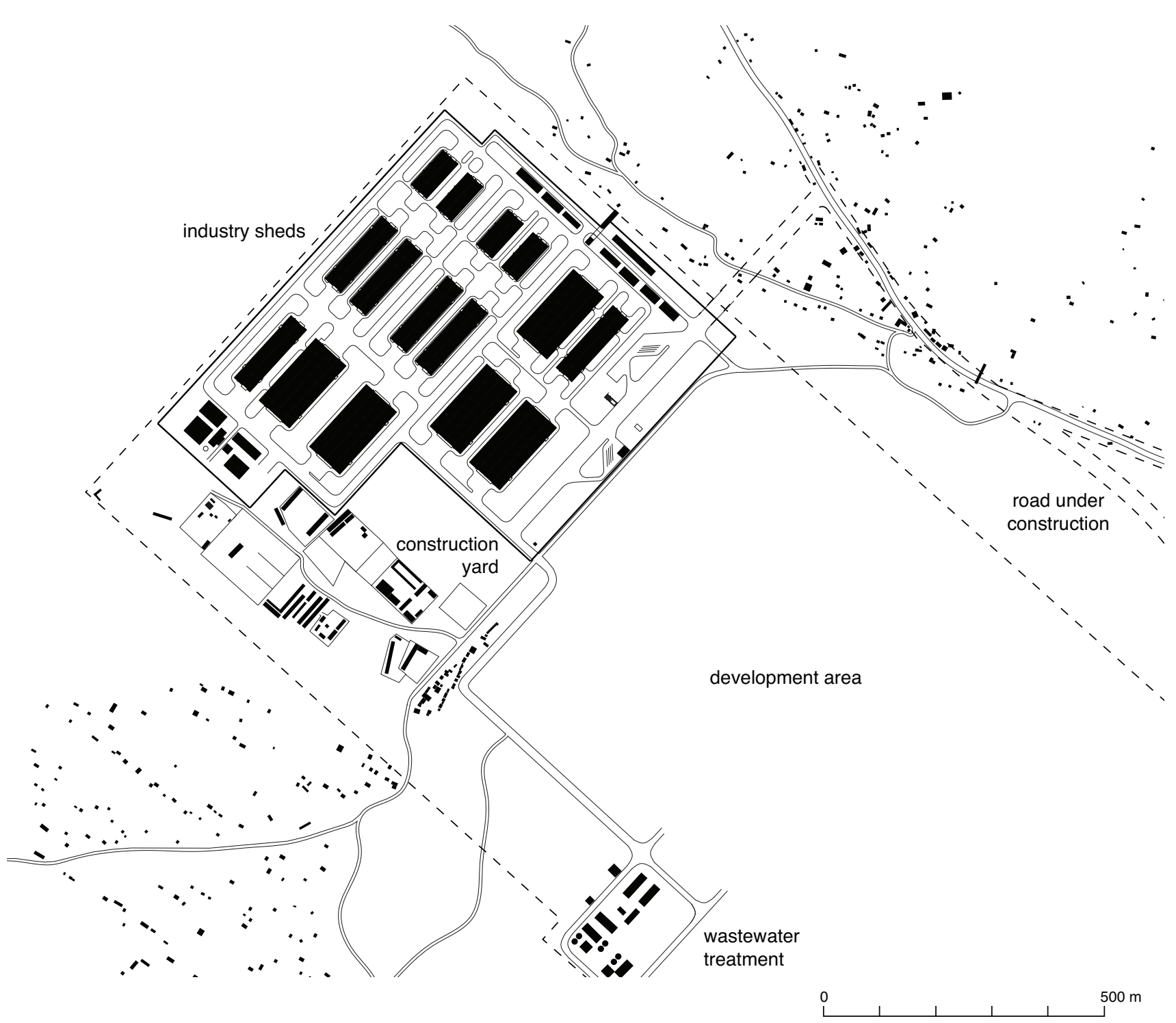

Figure 3. MIP, first construction phase (2018). Sources: Authors based on Google Maps, OpenStreetMap, IPDC (2015), and authors' interviews.

with an impermeable road corridor (on the Addis Ring Road development, also designed and implemented by the CCCC and fraught with similar problems, see Delz, 2015). Industry is also prone to consume immense electrical power and increase water scarcity, which is already at critical levels in the region. The huge monofunctional development areas and the fine-grain of existing and future urban texture appear as scalar mismatches posing issues concerning the planning governance constellations.

\subsection{Urban Planning Challenges Linked to Industrial Infrastructure Development}

The industrial-infrastructural complexes pose multiple governance challenges linked to mediating interests of stakeholders operating at very different scales. These stakeholders include local farmers and workers from rural areas, municipal planners, regional as well as fed- eral state institutions, transnational corporations and their suppliers, and globally active Chinese state-owned engineering companies. Last but not least, a range of foreign and international organisations are acting as development and/or investment consultants and capital providers. Power asymmetries between these stakeholders were already evident in the land allocation for industrial sites circa 2013. The location for the statedeveloped industry park, as well as for the private foreign-investment projects, was selected by Ethiopian Federal and Tigray Regional State's investment agencies, who went on to transfer publicly owned land from small tenant farmers (who received a very modest compensation) to foreign investors (who pay little or no rents on the land as an incentive). Government institutions operating at the national level actively promoted "strategic coupling" with global production networks by incentivisation, for example tax breaks and Development Bank of Ethiopia credits covering over $50 \%$ of initial investments 


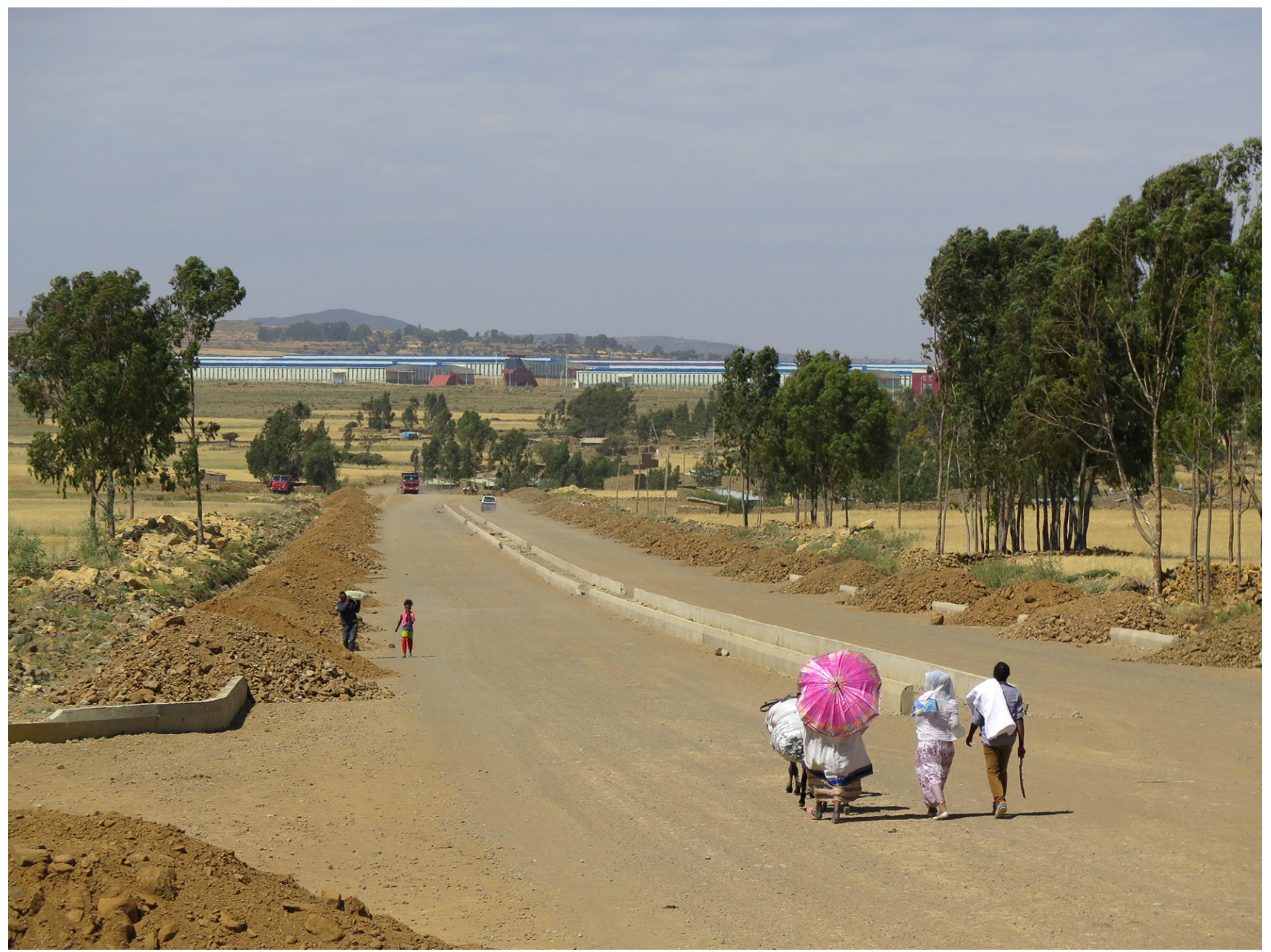

Figure 4. MIP and bypass under construction (2018).

by foreign companies, or through infrastructure provisioning. Meanwhile, locations could be allocated without engaging with the complexity of local realities and concerns. According to our interviews with textile company representatives, they were already exploring peripheral locations or beginning to develop their factories in 2013, but a 2014 land use analysis commissioned by Mekelle City Government in preparation for a revision of the city's structural plan made no mention of these largescale projects (Mekelle University, 2014). In interviews, local planners conceded that the large industrial developments were only retroactively integrated into local urban planning schemes and it was not until as late as 2016 that a structural plan proposal was elaborated as a basis for the development of the Mekelle urban region taking into account the emerging large industry areas within the city's expanding administrative boundaries (Mekelle University, 2016).

Connecting the industrial enclaves to networked transport and supply infrastructures has been realised incrementally, involving spatial planning and infrastructure provision actors operating at different scales. This also concerns the urban and rural fabric of social reproduction required to keep transnational commodity pro- duction running: At the time of our field work, the question of how to provide housing for tens of thousands of workers was still a matter of deliberation. Garment manufacturing workers would clearly not be able to afford the new condominium housing under construction close by (Delz, 2018), but how to finance schemes to develop more affordable housing was still unresolved, according to the MIP's management. In the meantime, some of the manufacturing companies renting sheds in the park had asked for permission to erect dormitories on adjacent land (for similar issues in other Ethiopian industry parks see Beyer \& Hagemann, in press). Apart from such factory-owned dorms planned with up to eight bunk-beds per room, the only viable housing option for workers was to rely on their personal or family networks, partly in rural, partly in informal settlements (Mezzadri, 2019).

Another key challenge is connectivity at different scales. National-level planning privileges infrastructural corridors for translocal commodity flows, ignoring more local mobility needs in urban and rural territories. According to a senior planner in Ethiopia's Federal Ministry of Transport, overland transport infrastructure was laid out in such broad strokes, even with regard to 
industrial development sites, that critical details such as feeder roads or cargo rail branches were addressed with a time lag. At the time of our visit to Mekelle, major transport infrastructure, including an 18-km bypass, was under construction in order to improve the connection of the export industry to the ports of Djibouti and Eritrea, with the CCCC as the main contractor for designing, engineering, and building (see Figure 2). The company's commissions included the design for a new dry port for customs processing near the airport and the future rail terminus (Kang'ereha, 2017; PwC et al., 2017). Here, a multi-modal hub was envisioned for transferring containers from the road to an electric railway line southward. The CCCC was also contracted to implement a $200-\mathrm{km}$ section of this railway line, as well as the entire Mekelle terminus station, co-financed by the Chinese state. Consequently, the engineering of most transport and industrial infrastructure for the commodity hub emerging in Mekelle relied on the design and construction expertise of one formidable global player in infrastructure provisioning, based in China. Although neither the rail terminus nor the multi-modal dry port project had proceeded beyond site allocation at the time of writing, they can be considered as significant factors in the strategic coupling with global production and important vectors of current and future urbanisation. Images of trains and the future countrywide rail network often feature in information materials for investors in MIP and other Ethiopian industry parks, and company representatives stated that the railway project contributed to their location choice in Mekelle. After painstaking land procurement processes, however, the building of the railway link was temporarily suspended in 2019 due to lack of funds. As the peace process with Eritrea raised hopes of shipping goods through Massawa port $400 \mathrm{~km}$ away, Mekelle's evolving commodity hub might ultimately connect to a different infrastructural link. But at the time of writing, the violent conflicts in the region have brought industry operations to a halt, jeopardising civilian life and future development.

\subsection{Industry Park and Infrastructure Provisioning: National Policy Frameworks and Bilateral and Multilateral Cooperation}

The making of a commodity hub in Mekelle is part of an ambitious national industrial and infrastructure development policy (see Figure 5). The MIP is not a singular case, but part of a national programme launched in the 2010s to build more than a dozen similar staterun industry parks across the country in order to facilitate integration into global production networks, specifically targeting the textile and garment industry (IPDC, 2015). International experiences in industrial-zone development are an important reference for the Ethiopian government, and most parks were designed and built by Chinese state-owned enterprises (United Nations Development Programme China \& International Poverty
Reduction Center in China, 2015; Weldesilassie et al., 2017; Zhang et al., 2018). At the parks, turn-key sheds, or land, water, and energy are available at very competitive prices, complemented by services such as advanced waste management, customs clearance, or administrative support for foreign businesses, including assistance with worker recruitment.

The national infrastructure development vision includes the construction of an impressive system of transport connections linking the various exportprocessing zones with transcontinental networks. Bilateral and multilateral partnerships are key to its financing and construction. Measures include the improvement of the overland road network, dry port facilities for international freight logistics (United Nations Development Programme Ethiopia, 2017) and a national electric railway network branching out from the railway connection between Addis Ababa and the port of Djibouti, which was re-established in 2018 in bilateral cooperation with China. The railway is an ambitious flagship project of state-led infrastructural development and Ethio-Chinese partnership, but transport planners question its actual exigency for the prioritised textile sector, as well as its high cost at a time when many rural areas still lack basic road access (authors' interviews in the autumn of 2018). As "renewable" power sources for manufacturing, Ethiopia's major rivers are being dammed by international engineering firms. In the field of infrastructure provisioning, China-also the biggest source of foreign direct investment in Ethiopia-has become the country's most important partner in financing as well as in designing and building the physical structures (Delz, 2015, 2016; Eom et al., 2018; Jalles d'Orey \& Prizzon, 2017; Nicolas, 2017; Ziso, 2017), but many other international stakeholders are competing on this promising market terrain.

\subsection{Industrial Infrastructure as Arena of Collaboration for New Transnational Actor Constellations: Global Production Networks and Global Development Cooperation}

As large export production enclaves are built up on the fringes of Ethiopian cities such as Mekelle and linked to privileged transport corridors, transnational involvement in infrastructure provisioning plays out in the formation of global production networks. The new industry parks have mostly attracted basic sewing operations by South-East Asian suppliers of ready-made garments to global fashion brands or retailers in Europe and North America. Producing in Ethiopia allows these firms to profit from preferential trade agreements, low wages, and other costs, as well as government incentives. Company managers and external observers stated that major European and US clothing retailers and brands actively encouraged their suppliers to move to Mekelle, and Ethiopia generally. The untarnished reputation of the country's new industry parks matched 


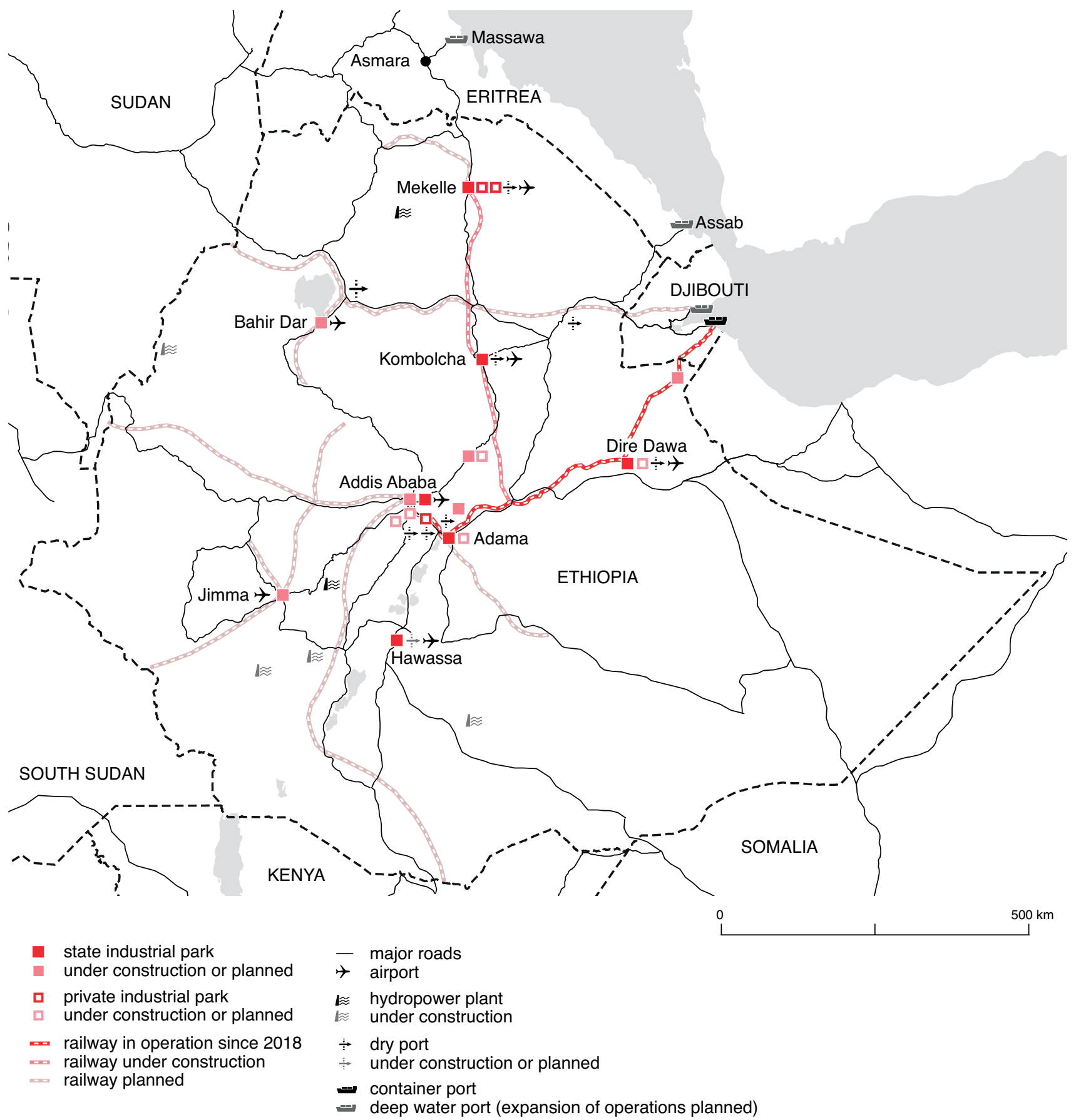

Figure 5. Industrial park and infrastructure development in Ethiopia (2018). Sources: Authors based on Google Maps, OpenStreetMap, Map Library, Ethiopian Investment Commission (2017), IPDC (2015), Embassy of Ethiopia in Brussels (2016), and authors' interviews.

the buyers' corporate social responsibility strategies in seeking cheap yet humane and safe working conditions. Further incentives were provided by qualification and vocational education programmes from European development agencies like Swedfund or Germany's Ministry for Development Cooperation (Federal Ministry for Economic Cooperation and Development, 2017; Swedfund, 2016). The parks operate not only as a field of collaboration between Ethiopian government institutions, transnational construction companies, and gar- ment firms, but are also supported by national and international development agencies and banks in numerous ways. This includes the mobilisation of planning knowledge and international experience in industry zone development, for example, conferences and training sessions to promote "sustainable industry areas" organised by Germany's development cooperation agency GIZ. Most of the international engagements are framed as catalysts of environmentally sustainable development and good governance practices, creating great numbers of 
jobs with the potential to reduce poverty and migration, but equally profitable opportunities for investment, garment sourcing, as well as the export of machinery, technology, and know-how from the agencies' home countries. However, observers point towards the significant risks and uncertainties of banking on the notoriously footloose clothing industry by offering export-oriented industrial enclaves with hardly any sustainable linkages to the domestic economy (Nicolas, 2017; Staritz et al., 2016; Weldesilassie et al., 2017; for a slightly more optimistic outlook see Altenburg et al., 2020). Beyond offering very low-wage jobs, the value captured in Ethiopia may therefore remain very low (Whitfield et al., 2020) and is subject to the extreme volatility of the global clothing industry. At the same time, the physical infrastructures catering to global production networks are bound to have questionable impacts on local urban development, which seems to be a secondary concern to stakeholders pursuing agendas of national and global scope but pose urgent tasks for more inclusive urban planning.

\section{The Grain Ports of Gran Rosario: A Global Centre of the Soy Industry in Argentina}

The metropolitan region of Gran Rosario is one of the world's largest hubs for the shipping and processing of grains (Giraudo, 2015) and an illustrative example for the power of this industry and its protagonists to shape the transformation processes of entire urban regions.

\subsection{Spatial Impacts of Soybean Shipping and Processing}

With approximately 1.3 million inhabitants, Gran Rosario is the third largest metropolitan region in Argentina. The city of Rosario, located on the banks of the Paraná River, has been a centre of grain trading, transport, and processing since the 1930s (Raposo, 2009). Today, the metropolitan region is home to more than 20 deepwater ports, most of them specialised in the shipment of grains and by-products in the metropolitan area which stretches over $60 \mathrm{~km}$ along the bank of the river. In recent decades soybeans and by-products became Argentina's major export commodities, accounting for more than $25 \%$ of the national exports, with Gran Rosario evolving to become the key node for soybean processing and shipping overseas. In addition to the expanding port, the railway lines, silos, and mills are now defining features of the region, linking the agricultural areas of the Argentinean Pampa with global markets (Galimberti, 2015). Today, the most important market for Argentina's grains is China, which received $96 \%$ of the country's soybean exports in 2018 (Calzada \& Ramseyer, 2019).

One of the most notable large-scale transformations can be observed within the municipal borders of the small town of Timbúes at the northern fringe of the metropolitan area (see Figure 6). The peri-urban area is dominated by huge integrated port and processing facilities, including soy crushing plants, grain dryers, and a bio-diesel refinery covering areas up to 200 ha and built on former agricultural land. The construction of the complexes was partly financed through specialised infrastructure investment funds or loans from different regional and global development banks (International Finance Corporation, 2009; Origlia, 2019; Ralev, 2013). The five national and multinational companies that are present in this area (see Figure 6 for details) accounted for $43 \%$ of Argentina's exports of grains and by-products in 2018 (Calzada \& Ramseyer, 2019). One of the major actors is the China Oil and Foodstuffs Corporation, a Chinese state-owned food processing and trading company which became an important player in Argentina's agroindustry through the acquisition of two large competitors. China Oil and Foodstuffs Corporation operates its biggest processing and port complex in Timbúes (see Figure 7) and is planning to expand its operations.

\subsection{Urban Planning Challenges Linked to the Soybean Processing and Shipping Infrastructures}

The vast port facilities in the north of the Gran Rosario region are highly securitised enclaves that have few links to surrounding suburban and peri-urban areas. Nevertheless, they assert a tremendous impact on their surrounding environment, posing serious challenges for sustainable local development. The ports' externalities include heavy emissions such as grain dust (see Figure 8) and massive traffic congestion. The latter partly results from inadequate road infrastructure serving the highcapacity ports, the exorbitantly high number of trucks entering the ports during harvest seasons, and insufficient parking areas for trucks in the ports ("Colapso logístico," 2021). Port expansions have also fuelled land use conflicts (Schweitzer, 2017). These have resulted, among other things, in the displacement of activities that sustain the livelihoods of the local population, such as smallscale river-bank fisheries (Roldán \& Godoy, 2020).

In addition, these large-scale transformations on the fringe of the metropolitan area, which have occurred with the involvement of the highest bodies of the national government, pose challenges in terms of integrated planning in the urban region: While only some of the municipalities gain revenues from the transport infrastructures and processing facilities, they heavily impact the greater region's economic development, environmental conditions, and traffic flows. Nevertheless, the local authorities of Timbúes, who have to directly deal with the interests of the powerful grain trading companies, do not have to align their land use plans with the planning of the other municipalities in the metropolitan region. Moreover, Timbúes does not participate in the voluntary association for metropolitan planning coordination ECOM. Instead, the municipalities that host ports in the province of Santa Fé, including Timbúes, created their own advocacy group to represent their particular interests vis-à-vis the provincial and national governments. 


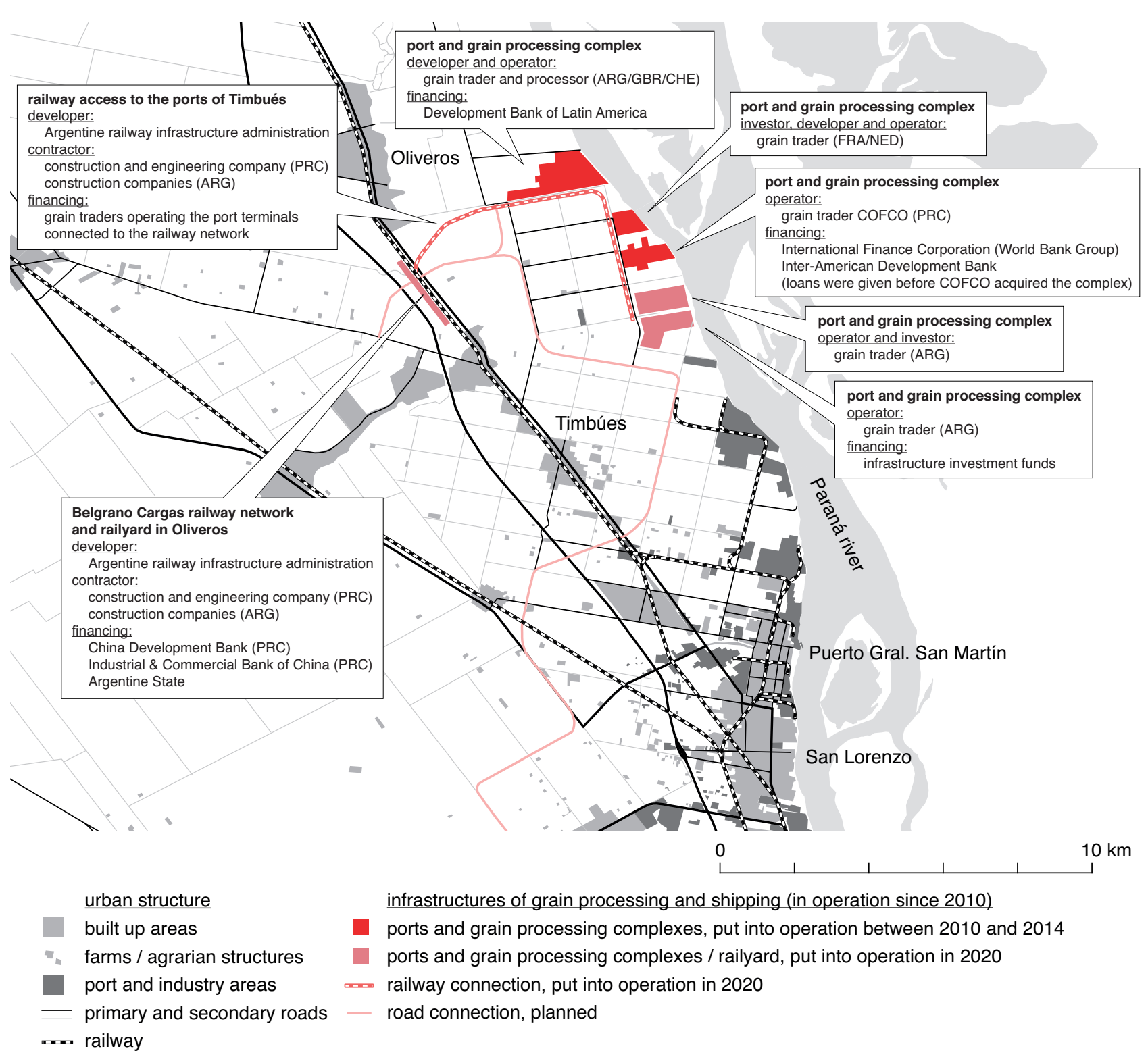

Figure 6. Infrastructure projects for soybean export and their actors around Timbúes, northern Gran Rosario. Sources: Authors based on Google Maps, OpenStreetMap, Calzada et al. (2017), International Finance Corporation (2009), Origlia (2019), Ralev (2013), and Vialidad Nacional (n.d.).

In order to mitigate the conflicts and risks caused by traffic at the peak times of the harvest seasons, the national state, in cooperation with provincial bodies and the municipalities, initiated actions to regulate heavy traffic. These include checkpoints operated by the traffic police, temporary road closures, and the assignment of specific routes to lorries. Another initiative led by the province's transport ministry brings together various provincial bodies, municipalities, and representatives of the transport industry to improve the coordination of traffic flows to the ports, inter alia through providing real-time information through messenger apps (“Colapso logístico," 2021). To increase the infrastructural capacities and to keep heavy traffic off the local road networks, a new motorway, projected as a public- private partnership, is intended to serve the grain ports in the north of Gran Rosario (Calzada et al., 2017; see Figure 6).

The infrastructures that enable transnational commodity flows to markets overseas and couple Argentina's rural areas with global production networks create frictions and put strain on suburban communities in Gran Rosario, resulting in specific patterns of spatial inequality. Due to the current mismatch of the infrastructures' locations and their spatial impacts, these problematic constellations cannot be resolved on the level of single municipalities but demand coordination on higher scales, as for instance happens in the case of cross-sectoral and multi-scalar initiatives by government bodies to prevent the collapse of the local road network at harvest times. 


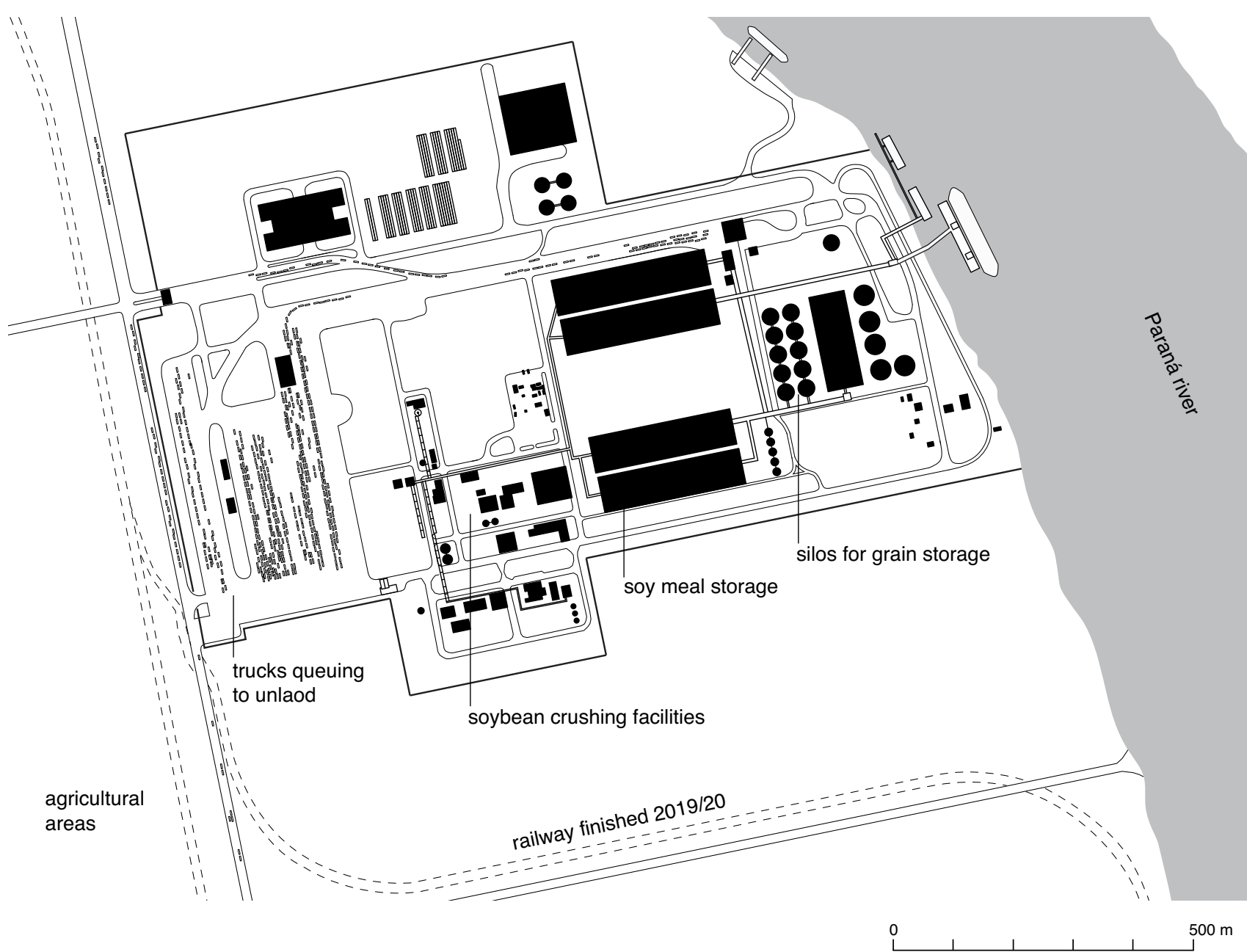

Figure 7. Soybean processing facility and China Oil and Foodstuffs Corporation harbour in Timbúes (2021). Sources: Authors based on Google Maps and OpenStreetMap.

\subsection{Bilateral Cooperation and the Globalised Agroindustry as Drivers of Infrastructure Development}

Currently, soybeans are mostly transported by lorry in Argentina (Gómez Lende \& Velázquez, 2018), hastened by the fact that the railway network has been fragmented and partly decaying since the late 20th century, in the context of the country's neoliberal restructuring. Despite this, the ports around Timbúes are an endpoint of one of Argentina's major current transportation infrastructure projects, namely the renovation of the main corridors of the Belgrano Cargas railway network.

In Timbúes and the neighbouring municipality of Oliveros, new rail tracks to the port terminals and a new rail yard have been constructed as part of the project, co-financed by the companies operating the ports and processing facilities (see Figure 6). Transport infrastructure development in Argentina strongly reflects the needs of the country's extractive industries, in particular the agroindustry: Many of the country's main road and railway corridors, as well as the infrastructures for inland navigation, connect regions of intense agricultural activ- ities to seaports that enable access to overseas markets. The renovation of the Belgrano Cargas network allows for better integration of territories in Argentina's north (see Figure 9), which still hold great potential for the expansion of soybean cultivation, into global agro-industrial production networks (Gómez Lende \& Velázquez, 2018) by increasing railway capacity and dramatically reducing travel time. In addition, the major grain traders have become important actors in the freight transport market as they operate port terminals, railway lines, and lorry fleets. Most of the companies whose terminals in Timbúes are being connected to the Belgrano Cargas network are already customers of Trenes Argentinos Carga, the state-owned freight railway company operating the network. In the past ten years grains and by-products accounted for up to $80 \%$ of the Belgrano Cargas railway's transported volumes. Therefore, it can be assumed that these companies generate a considerable share of the cargo transported as well as the future demand for planned services. The five companies are all members of the Rosario Board of Trade, a local business organisation that represents the interests of the agricultural and port 


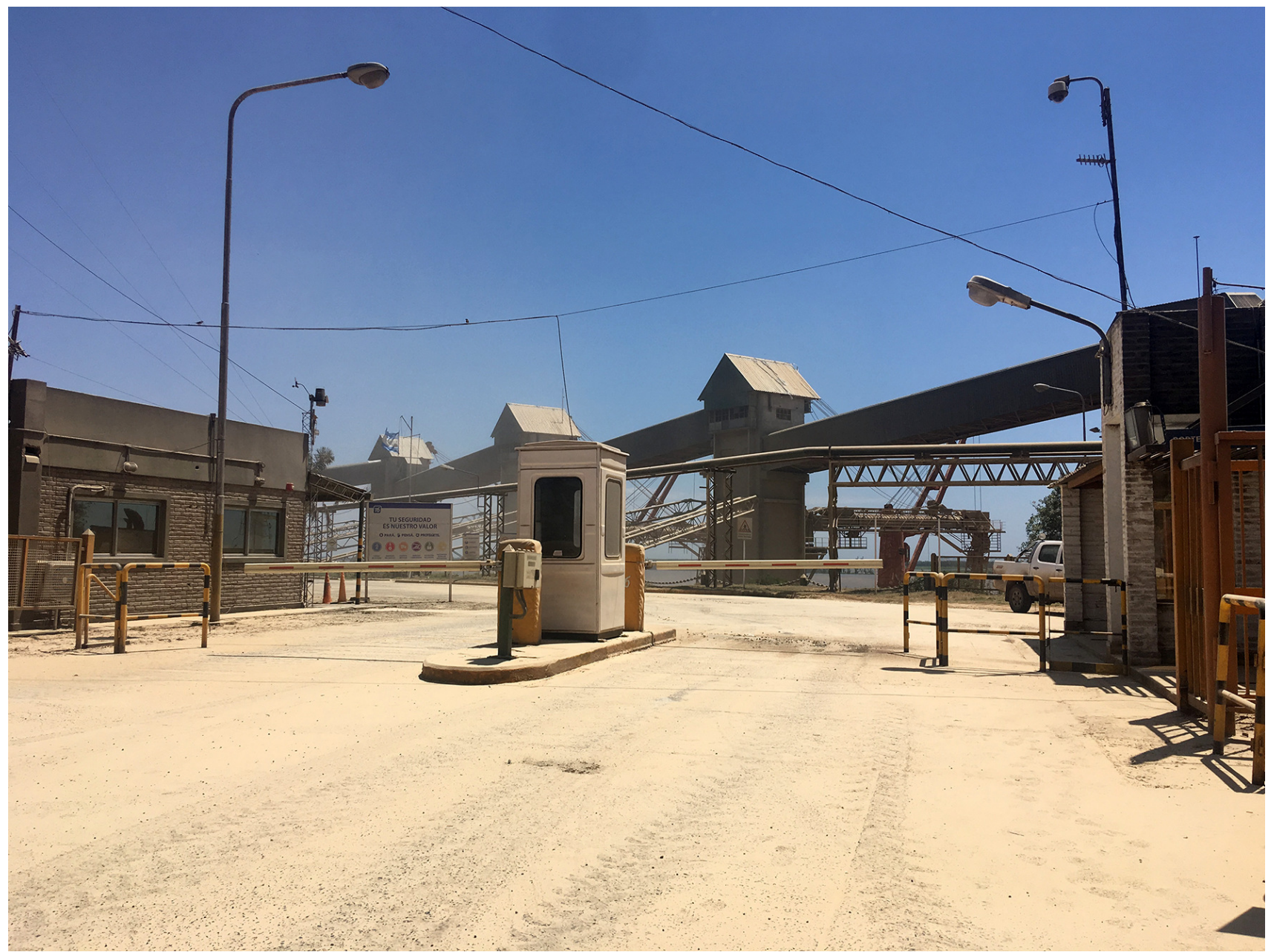

Figure 8. Entrance of a port in northern Gran Rosario, covered in grain dust (2018).

industries, among others. It is seen as an influential voice of the respective sectors in local, provincial, and national politics (authors' interviews, 2018).

The railway renovation project is directed by Argentina's federal transport ministry and coordinated by a state-owned railway infrastructure company. Planning decisions are taken by national-level authorities and only need to be approved by the municipalities directly affected. The project is financed by the Argentinean state and a \$4-billion loan from two Chinese banks (China Development Bank Corporation and the Industrial and Commercial Bank of China Limited), linked to a contract with the China Machinery and Engineering Corporation (Ministerio de Transporte, 2017a). The contract with China Machinery and Engineering Corporation includes the purchase of rolling stock and construction materials from China, as well as respective technical services and staff training. The construction work, on the other hand, is the responsibility of Argentinean companies. By late 2019, $900 \mathrm{~km}$ of the targeted 1,845 km of the Belgrano Cargas network had been renovated. The expansion of the network is currently under consideration, as mentioned by the Argentine ambassador to China in an interview in early 2021 (Dinatale, 2021).
The Belgrano Cargas project is embedded in the multilateral South American infrastructure planning initiative IIRSA-COSIPLAN and is also part of greater infrastructure initiatives with Chinese involvement in Argentina, which include loans for passenger and further cargo railway projects as well as for energy infrastructures (The Dialogue, n.d.).

On the scale of the urban region, the renovation and local expansion of the Belgrano Cargas network might contribute to tackling the dominance of road-borne commodity transport and the related problems it causes in the respective municipalities. For the grain traders, the project can also be seen as a solution to the bottleneck situation that the urban spaces represent within their logistical networks. The renovation of the railway network and the expansion of the ports in Gran Rosario also strengthen and consolidate the region as a central node within the global production network of the soybean industry. These infrastructures also fix large amounts of capital in space and thus contribute to the persistence of the extractivist model of economic development focused on the export of soybeans and by-products, creating in turn critical relations of dependency on the global market for this specific commodity (Gómez Lende \& 
Velázquez, 2018). The boom of the soybean industry has deeply transformed Argentina's landscape and the country's social structure in recent decades. On the one hand, many actors involved in the sector benefited when the soybean industry was thriving, the respective state revenues allowed for redistributive measures and

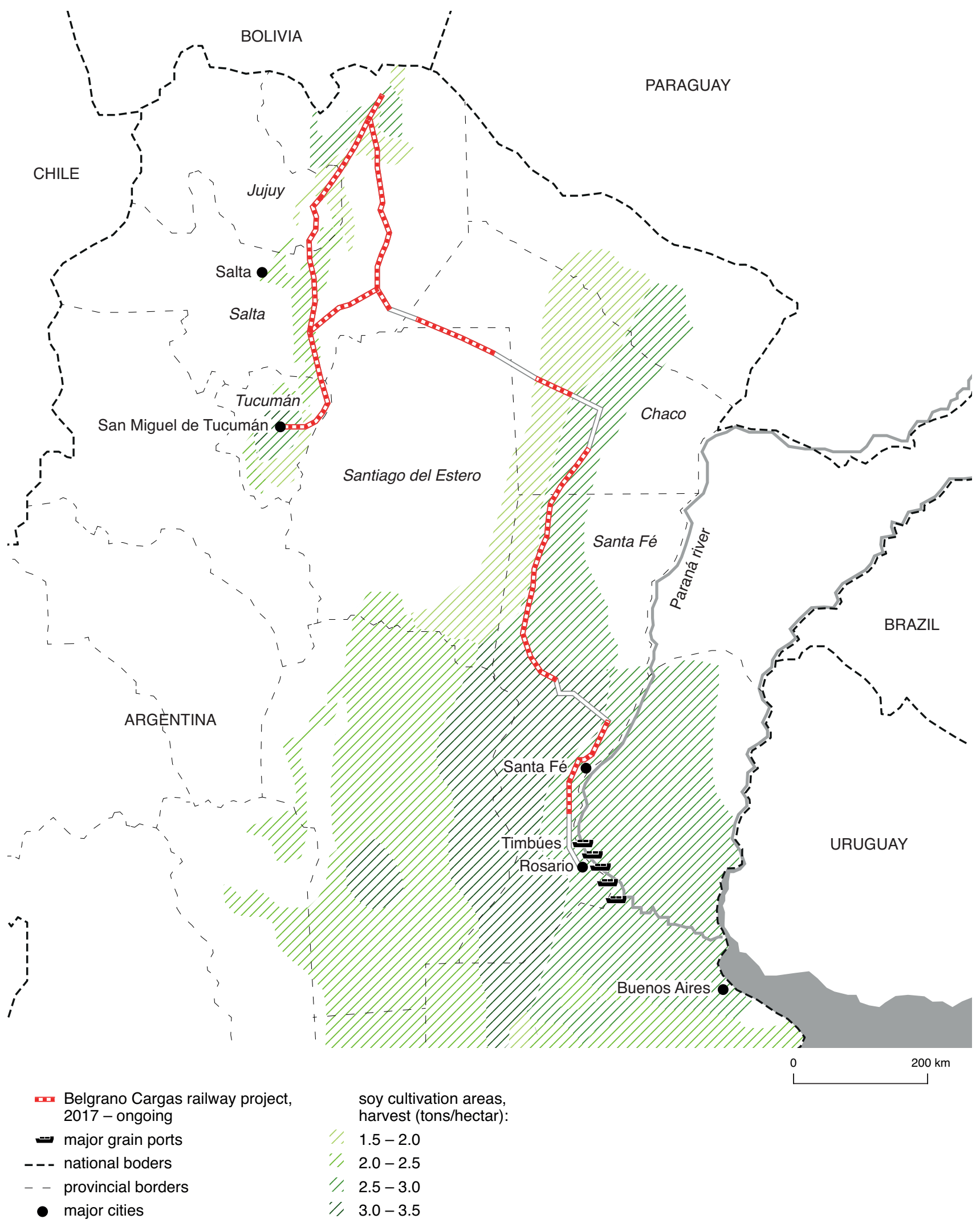

Figure 9. The Belgrano Cargas railway renovation project. Sources: Authors based on Google Maps, OpenStreetMap, Global Yield Gap Atlas (n.d.), and Ministerio de Transporte (2017b). 
a considerable processing industry was developed in the soybean sector (Dobelmann, 2012; Sly, 2017). On the other hand, large parts of the value generated are being captured by very few, mostly transnationally active companies, amongst them the large traders. Furthermore, the development of the soybean industry has been accompanied by an enforcement of existing, and the creation of new, patterns of inequality (e.g., Dobelmann, 2012; Gras, 2013). This has occurred particularly through the spatial expansion of the industrialised cultivation of soybeans and environmental degradation linked to the intensive deployment of pesticides and monocultural modes of farming (Gómez Lende, 2017). Improving the connectivity to the northern provinces through the renovation of the Belgrano Cargas network, and thereby integrating new territories into the global production networks of the soybean industry, will very likely contribute to this development, as the considerable increase in the transportation of grains originating from the provinces Salta and Chaco in 2020 (Ministerio de Transporte, 2021) indicates. These are also the same provinces where massive deforestation can be observed (Patel, 2020). Other results of the transformations of rural Argentina through the soybean sector are, inter alia, the exclusion of former peasants from participating in agricultural activities and rural-urban flows of migration (Viale, 2017), the latter also greatly affecting Gran Rosario.

The case study of Timbúes has shown that the development of the peri-urban landscape of the soybean industry is being decisively shaped by translocal relations which encompass the global soybean production networks and the bilateral railway infrastructure project. Both actor constellations are tightly entangled, and in both-besides the significant role of Argentina's national government-Chinese companies have become central figures.

\section{Conclusion}

In this article we employed a multi-scalar and relational research approach in order to add crucial dimensions to the understanding of industrial site development in a globalised world. We argue that mobilising methodological tools from related disciplines, such as economic geography, can add essential new perspectives and, thus, make the case for a more comprehensive methodological approach to planning studies. As a result, entanglements between spatial planning, global production networks and infrastructure provisioning on the scales of built forms, urban regions, and translocal infrastructure networks are revealable.

More concretely, the cases discussed in this article showed the following:

- Firstly, we have shown how planning of infrastructures and the transformation of local built environments in Mekelle, Ethiopia, and Rosario, Argentina involve a transnational stakeholder net- work and new actor constellations. Both cases illustrate the deep entanglement of local industrial site development and the provisioning of large physical infrastructures and global production networks, supporting the claim that "urban development is increasingly shaped by transnational and translocal relations" (Söderström, 2014, p. 171). Indeed, both cases point towards a significant shift in planning power towards actors in global production networks supported by national governments, especially in the initial planning and implementation phases. In both cases, local planners were left to make do with the new realities, retrospectively stitching together new industrial complexes and existing cities and retroactively planning for access roads or housing, as if an afterthought. In addition, municipalities often lack the necessary capacities to mitigate the effects of such infrastructure projects as they are poorly mandated and resourced vis-à-vis the national government.

- Secondly, by tracing the transnational actor constellations of industry and infrastructure development beyond the local and national scales of planning, we were able to demonstrate how global production networks can be instrumental in the spatial dynamics transforming specific places into commodity hubs. Local industrial Chinese stakeholder and state interests are involved in these networks to a different degree and with different aims: Enhancing connectivity in Rosario promises a stabilisation of China's import demands for agricultural staples and qualifies the region's function as the soybean industry's major hub. In contrast, industrial and infrastructural development in Ethiopia offers opportunities for the relocation of production capacities in the low-wage textile industry to a preferential trade area. In both cases, however, the infrastructure projects foster the import of industry supplies and construction technology from China. Moreover, transnational enterprises are deeply involved in financing, ownership, operation, and construction of the infrastructures under study. They emerge as potent actors able to channel the global flows of commodities and value generation enabled by these structures. In both case studies, large construction engineering companies and banks from China are key players, orchestrating a large network of Chinese companies from the infrastructure, transportation, and construction sectors involved in the projects. In these networks the engineering companies and banks act as intermediaries for loans and coordinate the supply of construction materials and technology, as well as the provisioning of the expertise from China. These relations materialise in the provided infrastructures, and thereby in the resulting built environments constituting transnational urban spaces. 
This phenomenon warrants a closer study of how urban spaces are produced in asymmetrical interaction between transnational, national, and municipal actors-each with potentially diverse and conflicting agendas-and the local residents, not least because it is the livelihoods of local residents that stand to be most heavily impacted by such transformations as could be observed in Mekelle and Gran Rosario.

- Thirdly, the spatial analysis of both cases has confirmed the massive physical implications of infrastructure provisioning for global production in both urban regions. The large-scale interventions under study constitute not only important vectors of spatial transformation and likely future urbanisation. In both cases, uneven urban textures have emerged which evoke the inequities and risks described by Graham and Marvin (2001) as "splintering urbanism": Investments and infrastructure provisioning concentrate in highly connected enclaves catering to globalised production and linked to transnational networks, while existing settlements and their inhabitants face negative externalities, such as increased water scarcity, pollution, and unresolved housing needs. Providing the necessary infrastructure, i.e., with regard to transportation and housing, that meets the needs of both the global production networks and the respective workers and local residents seems to be a major challenge for local authorities. Thus, the provisioning of large-scale infrastructures for global production can complicate efforts of planning for sustainable local development.

What consequences might these findings have for more sustainable planning approaches? Both cases have shown that powerful transnational actor constellations, the primacy of industrial development, and the leading role of planning authorities at the national level result in the bypassing of local authorities and the neglect of integrated urban development strategies, creating major challenges for planning at an urban and regional scale. Local authorities appear poorly mandated, resourced, and capacitated to negotiate and steer developments towards more favourable outcomes. Both cases also reveal specific vulnerabilities and governance failures which, together, map out a broad field for potential action: In Rosario, the lack of effective cooperation between municipalities leaves the region exposed to destructive competition and deal-makings with negative consequences; in Mekelle, local authorities are left at the receiving end of planning for industrialisation and infrastructure development in which primarily national and global actors are engaged.

Our article clearly shows that the transnational setups described can have major implications for the governance of infrastructure provisioning, implications which need to be understood and considered in strategic plan- ning approaches for the future development of such industry locations and in efforts to mitigate the corresponding negative effects on local contexts.

\section{Acknowledgments}

We would like to thank the editors and the anonymous reviewers for their comments and suggestions that helped to improve the argument of this article. We would also like to thank our research partners Melaku Tanku Gebremariam and Eyasu Kumera for sharing their observations at the 2019 International Conference on Sustainable Industrial Areas in Addis Ababa. The article partly presents research findings of the project "Transnational Production Spaces" (2016-2019), funded by the Deutsche Forschungsgemeinschaft (DFG) under grant agreement No. MI 1893/2-1. The publication was funded by the German Academic Exchange Service (DAAD) with funds of the German Federal Ministry for Economic Cooperation (BMZ).

\section{Conflict of Interests}

The authors declare no conflict of interests.

\section{References}

Altenburg, T., Chen, X., Lütkenhorst, W., Staritz, C., \& Whitfield, L. (2020). Exporting out of China or out of Africa? Automation versus relocation in the global clothing industry (Discussion Paper No. 1/2020). Deutsches Institut für Entwicklungspolitik. http://hdl. handle.net/10419/213279

Anand, N., Gupta, A., \& Appel, H. (Eds.). (2018). The promise of infrastructure. Duke University Press.

Arboleda, M. (2016). Spaces of extraction, metropolitan explosions: Planetary urbanization and the commodity boom in Latin America. International Journal of Urban and Regional Research, 40(1), 96-112.

Bair, J., \& Gereffi, G. (2001). Local clusters in global chains: The causes and consequences of export dynamism in Torreon's blue jeans industry. World Development, 29(11), 1885-1903.

Beyer, E., \& Hagemann, A. (in press). Transnational urban spaces. Production locations of the global clothing industry in Ethiopia. In L. Moretto, A. Fisher, \& G. Faldi (Eds.), African cities through local eyes. Experiments in place-based planning and design. Springer.

Beyer, E., Elsner, L.-A., \& Hagemann, A. (in press). Infrastructures for global production in Ethiopia and Argentina. Commodity chains and urban spatial transformation. In I. Castillo Ulloa, C. Haid, A. Million, \& N. Baur (Eds.), Spatial transformations. Kaleidoscopic perspectives on the refiguration of spaces. Routledge.

Beyer, E., Hagemann, A., \& Misselwitz, P. (2020). Commodity flows and urban spaces. An introduc- 
tion. Articulo-Journal of Urban Research, 2020(21). https://doi.org/10.4000/articulo.4522

Breul, M., Revilla Diez, J., \& Sambodo, M. T. (2019). Filtering strategic coupling: Territorial intermediaries in oil and gas global production networks in Southeast Asia. Journal of Economic Geography, 19(4), 829-851.

Burchardt, M., \& Höhne, S. (2015). The infrastructures of diversity: Materiality and culture in urban space. New Diversities, 17(2), 1-13.

Calzada, J., \& Ramseyer, F. (2019, March 1). ¿Quiénes fueron los principales exportadores argentinos de granos y subproductos y a dónde fue la mercadería en 2018? [Who were the main Argentine exporters of grains and by-products and where did the goods go in 2018?]. Bolsa de Comercio de Rosario. http://www.bcr.com.ar/es/mercados/investigaciony-desarrollo/informativo-semanal/noticiasinformativo-semanal/quienes-fueron

Calzada, J., Ferrer, N., \& Calivari, J. I. (2017, December 1). Participación público privada y ejecución de obras viales [Public-private partnerships and the implementation of road works]. Bolsa de Comercio de Rosario. http://www.bcr.com.ar/es/mercados/ investigacion-y-desarrollo/informativo-semanal/ noticias-informativo-semanal/participacion

Coe, N., \& Yeung, H. W.-C. (2015). Global production networks: Theorizing economic development in an interconnected world. Oxford University Press.

Colapso logístico: El lado B de la cosecha [Logistical collapse: The downside of the harvest]. (2021, May 7). AGROCLAVE. https://www.agroclave.com.ar/ colapso-logistico-el-lado-b-la-cosechan2659080.html

Delz, S. (2015). Development cooperation at all costs: How global actors and concepts influence urban and rural transformation. Case studies from Ethiopia. ETH Zurich.

Delz, S. (2016). Who built this? China, China, China! Expanding the Chinese economy through mutual benefit and infrastructure construction. In M. Angélil \& D. Hebel (Eds.), Cities of change-Addis Ababa. Transformation strategies for urban territories in the 21st century (pp. 198-205). Birkhäuser.

Delz, S. (2018). Low-cost at a high price-financial, spatial and social inclusion challenged by individual home-ownership and standardized housing blocks. TRIALOG, 3(130/131), 20-26.

Dinatale, M. (2021, May 23). Sabino Vaca Narvaja: "China demostró que será un aliado clave para nuestra recuperación" [Sabino Vaca Narvaja: "China has shown that it will be a key ally in our recovery"]. El Cronista. https://www.cronista.com/economiapolitica/no-publicar-china-demostro-que-es-unaliado-clave-para-la-recuperacion-de-la-argentina

Dobelmann, A. (2012). Neue Strukturen der Abhängigkeit: Das globale Produktionsnetzwerk der Gensojaproduktion in Argentinien [New structures of dependency: The global production network of GM soy production in Argentina]. PERIPHERIE, 32(128), 475-499.

Easterling, K. (2014). Extrastatecraft: The power of infrastructure space. Verso.

Embassy of Ethiopia in Brussels. (2016). Industrial park development in Ethiopia. The Ethiopian Messenger, 2016(2), 15-19.

Enns, C. (2018). Mobilizing research on Africa's development corridors. Geoforum, 88, 105-108.

Eom, J., Brautigam, D., \& Benabdallah, L. (2018). The path ahead: The 7th forum on China-Africa cooperation (Briefing Paper 01/2018). China Africa Research Initiative.

Ethiopia National Planning Commission. (2016). Ethiopia Growth and Transformation Plan II (GTP II). Federal Democratic Republic of Ethiopia.

Ethiopian Investment Commission. (2017). An investment guide to Ethiopia (EIC Ref. No. 03/2017).

Federal Ministry for Economic Cooperation and Development. (2017, April 4). Development Minister Müller launches TVET centre for the textile sector in Ethiopia [Press release]. http://www.bmz.de/20170404-1en

Galimberti, C. I. (2015). La reinvención del Río. Procesos de transformación de la ribera de la región metropolitana de Rosario, Argentina [The reinvention of the river. The transformation of the riversides of the metropolitan region of Rosario, Argentina]. UNR Editora.

Gao, B., Dunford, M., Norcliffe, G., \& Liu, Z. (2017). Capturing gains by relocating global production networks: The rise of Chongqing's notebook computer industry, 2008-2014. Eurasian Geography and Economics, 58(2), 231-257.

Giraudo, M. E. (2015). Commodity hubs: Production of space and new geographies of capital. Alternautas, 2(1), 79-87.

Gläser, J., \& Laudel, G. (2010). Experteninterviews und qualitative Inhaltsanalyse als Instrumente rekonstruierender Untersuchungen [Expert interviews and qualitative content analysis as tools for reconstructive studies] (4th ed.). Springer.

Global Yield Gap Atlas. (n.d.). Argentina. Description of cropping systems, climate, and soils. https://www. yieldgap.org/argentina

Gómez Lende, S. (2017). Usos del territorio, acumulación por desposesión y derecho a la salud en la Argentina contemporánea: El caso de la soja transgénica [Land use, accumulation by dispossession, and the right to health in contemporary Argentina: The case of transgenic soybeans]. GEOgraphia, 19(39), 3-15.

Gómez Lende, S., \& Velázquez, G. (2018). Soybean agribusiness in Argentina (1990-2015): Socioeconomic, territorial, environmental, and political implications. In G. Egilmez (Ed.), Agricultural value chains (pp. 117-136). InTech.

Goodfellow, T., \& Huang, Z. (2021). Contingent infrastructure and the dilution of 'Chineseness': Reframing roads and rail in Kampala and Addis Ababa. Envi- 
ronment and Planning A: Economy and Space, 53(4), 655-674.

Graham, S., \& Marvin, S. (2001). Splintering urbanism: Networked infrastructures, technological mobilities and the urban condition. Routledge.

Gras, C. (2013). Agronegocios en el Cono Sur: Actores sociales, desigualdades y entrelazamientos transregionales [Agribusiness in the Southern Cone: Social actors, inequalities, and transregional entanglements] (Working Paper No. 50). desiguALdades.net. https://www.desigualdades.net/Resources/ Working_Paper/50-WP-Gras-Online-revised.pdf? 1380020114

Grubbauer, M. (2015). Circulating knowledge, marketization and norm-making: International developers and construction firms in Eastern Europe since 2000. Global Networks, 15(3), 288-306.

Harris, A. (2013). Concrete geographies: Assembling global Mumbai through transport infrastructure. City, 17(3), 343-360.

Hein, C. (2018). Oil spaces: The global petroleumscape in the Rotterdam/The Hague area. Journal of Urban History, 44(5), 887-929.

Henderson, J., Dicken, P., Hess, M., Coe, N., \& Yeung, H. W.-C. (2002). Global production networks and the analysis of economic development. Review of International Political Economy, 9(3), 436-464.

Industrial Parks Development Corporation. (2015). Industrial Parks Development Corporation [Brochure].

International Finance Corporation. (2009, July 16). IFC respalda expansión de infraestructura de procesamiento de soja en un puerto en Argentina [IFC backs expansion of soybean processing infrastructure at port in Argentina] [Press release]. https:// pressroom.ifc.org/all/pages/PressDetail.aspx? ID $=23896$

Jacobs, W., \& Lagendijk, A. (2014). Strategic coupling as capacity: How seaports connect to global flows of containerized transport. Global Networks, 14(1), 44-62. https://doi.org/10.1111/glob.12035

Jalles d'Orey, M. A., \& Prizzon, A. (2017). An 'age of choice' for infrastructure financing? Evidence from Ethiopia. Overseas Development Institute.

Kanai, J. M., \& Schindler, S. (2019). Peri-urban promises of connectivity: Linking project-led polycentrism to the infrastructure scramble. Environment and Planning A: Economy and Space, 51(2), 302-322.

Kang'ereha, D. (2017). Ethiopia's US $\$ 100 m$ dry port design concluded. Construction Review Online. https://constructionreviewonline.com/2017/11/ ethiopias-us-100m-dry-port-design-concluded

LeCavalier, J. (2016). The rule of logistics: Walmart and the architecture of fulfilment. University of Minnesota Press.

Leigh Star, S. (1999). The ethnography of infrastructure. American Behavioral Scientist, 43(3), 377-391.

Lin, W. (2019). Infrastructure's expenditures: Changi airport, food cargo and capital's technosphere. Interna- tional Journal of Urban and Regional Research, 43(1), 76-93.

Liu, Z., Schindler, S., \& Liu, W. (2020). Demystifying Chinese overseas investment in infrastructure: Port development, the Belt and Road Initiative and regional development. Journal of Transport Geography, 87, Article 102812. https://doi.org/10.1016/ j.jtrangeo.2020.102812

Lyster, C. (2016). Learning from logistics: How networks change our cities. Birkhäuser.

McCann, E., \& Ward, K. (2012). Assembling urbanism: Following policies and 'studying through' the sites and situations of policy making. Environment and Planning A: Economy and Space, 44(1), 42-51.

McFarlane, C., \& Rutherford, J. (2008). Political infrastructures: Governing and experiencing the fabric of the city. International Journal of Urban and Regional Research, 32(1), 363-374.

Mekelle University. (2014). Revision of structure plan of Mekelle City. Spatial analysis (land use analysis). Unpublished document.

Mekelle University. (2016). Mekelle city structure plan revision. Final framework plan report/proposal. Unpublished document.

Mezzadri, A. (2019). On the value of social reproduction. Radical Philosophy, 2(4), 33-41.

Ministerio de Transporte. (2017a). El Gobierno Nacional amplió USD $1600 \mathrm{M}$ el crédito para recuperar el FFCC Belgrano Cargas [The national government extends the loan for the renovation of the FFCC Belgrano Cargas by 1.6 billion USD]. Argentina.gob.ar. https://www.argentina.gob.ar/noticias/el-gobiernonacional-amplio-usd-1600-m-el-credito-pararecuperar-el-ffcc-belgrano-cargas

Ministerio de Transporte. (2017b). Renovaron más de $200 \mathrm{~km}$ de vías del Belgrano Cargas [More than 200 $\mathrm{km}$ of the Belgrano Cargas tracks have been renovated]. Argentina.gob.ar. https://www.argentina. gob.ar/noticias/renovaron-mas-de-200-km-de-viasdel-belgrano-cargas

Ministerio de Transporte. (2021). Trenes Argentinos Cargas transportó un 15\% más durante el 2020 [Trenes Argentinos Carga increased their volume of transported goods by $15 \%$ in 2020]. Argentina.gob.ar. https://www.argentina.gob.ar/noticias/trenesargentinos-cargas-transporto-un-15-mas-duranteel-2020

Narins, T. P., \& Agnew, J. (2020). Missing from the map: Chinese exceptionalism, sovereignty regimes and the Belt Road Initiative. Geopolitics, 25(4), 809-837.

Negese, D. S., Guchale, E. N., Aregawi, H. G., Hirbaye, K. B., \& Gebremeskel, S. A. (2017). City profile Mekelle (Report prepared for the Social Inclusion and Energy Management for Informal Urban Settlements Project). Mekelle University. https://mdl. donau-uni.ac.at/ses/pluginfile.php/314/mod_page/ content/4/City\%20Profile\%20Mekelle.pdf

Nicolas, F. (2017). Chinese investors in Ethiopia: 
The perfect match? Ifri and OCP Policy Center. https://www.ifri.org/sites/default/files/atoms/files/ nicolas_chinese_investors_ethiopia_2017.pdf

Origlia, G. (2019, December 11). Con US\$7,5 millones. AGD completó el financiamiento para el puerto de Timbúes [With 7.5 million USD AGD completed financing for the port of Timbúes]. La Nación. https://www.lanacion.com.ar/economia/campo/ con-us75-millones-agd-completo-financiamientopuerto-nid2314847

Parnreiter, C. (2015). Strategic planning, the real estate economy, and the production of new spaces of centrality. The case of Mexico City. Erdkunde, 69(1), 21-31.

Patel, K. (2020). Deforestation in Argentina's Gran Chaco. NASA Earth Observatory. https://earth observatory.nasa.gov/images/146731/deforestationin-argentinas-gran-chaco

Peck, J., \& Theodore, N. (2010). Mobilizing policy: Models, methods, and mutations. Geoforum, 41, 169-174.

PwC, IPE Global Triple Line, \& Ethiopian Development Research Institute. (2017). Green climate compatible urban industrial development in Ethiopia. Strategy and projects for the Kombolcha-Mekele industrial corridor (Final report). https://cdkn.org/wpcontent/uploads/2018/02/Final-Reporting-ClimateCompatible-Urban-Industrial-project-developmentand-Investment-Plan.pdf

Ralev, R. (2013). Renova to launch Timbues port grain terminal. Renewables Now. https://renewables now.com/news/renova-to-launch-timbues-portgrain-terminal-367947

Raposo, I. (2009). Reestructuración ferroviaria en Argentina y cambios en el territorio. Una verificación en la Región Metropolitana Rosario [Railway restructuring in Argentina and territorial changes. The case of the Rosario Metropolitan Region]. Revista Transporte y Territorio, 1, 25-56.

Rode, P., Terrefe, B., \& da Cruz, N. F. (2020). Cities and the governance of transport interfaces: Ethiopia's new rail systems. Transport Policy, 91, 76-94.

Roldán, D., \& Godoy, S. (2020). Conflictos territoriales y culturales en la renovación del frente costero, Rosario (Argentina) [Territorial and cultural conflicts in the renewal of the waterfront, Rosario (Argentina)]. EURE-Revista de Estudios Urbano Regionales, 46(138), 95-116.

Roy, A. (2009). The 21st-century metropolis: New geographies of theory. Regional Studies, 43(6), 819-830.

Schindler, S., \& Kanai, J. M. (2019). Getting the territory right: Infrastructure-led development and the re-emergence of spatial planning strategies. Regional Studies, 55(1), 40-51.

Scholvin, S., Breul, M., \& Revilla Diez, J. (2019). Revisiting gateway cities: Connecting hubs in global networks to their hinterlands. Urban Geography, 40(9), 1291-1309.
Schweitzer, M. (2017). San Lorenzo y Puerto General San Martín. Territorios atravesados por dinámicas globales [San Lorenzo and Puerto General San Martín. Territories crossed by global dynamics]. América Latina Hoy, 75, 101-124.

Sly, M. J. H. (2017). The Argentine portion of the soybean commodity chain. Palgrave Communications, 3(1), Article 17095. https://doi.org/10.1057/ palcomms.2017.95

Söderström, O. (2014). Cities in relations. Trajectories of urban development in Hanoi and Ouagadougou. Wiley.

Staritz, C., Plank, L., \& Morris, M. (2016). Global value chains, industrial policy, and sustainable development-Ethiopia's apparel export sector. International Centre for Trade and Sustainable Development.

Swedfund. (2016, May 26). Swedfund, H\&M and $D B L$ Group create 4,000 jobs in Ethiopia [Press release]. http://swedfund-com.mynewsdesk.com/ pressreleases/swedfund-h-m-and-dbl-groupcreate-4-000-jobs-in-ethiopia-1419599

Teka, D. (2020). Mekelle City: Secondary cities project. Office of the Geographer and Global Issues (GGI) in the Bureau of Intelligence and Research. https:// storymaps.arcgis.com/stories/31dcbc444368466dae 174ecee1f4393d

The Dialogue. (n.d.). China-Latin America finance database [Data set]. https://www.thedialogue.org/ map_list

United Nations Development Programme China, \& International Poverty Reduction Center in China. (2015). If Africa builds nests, will the birds come? Comparative study on special economic zones in Africa and China (Working Paper 06.2015).

United Nations Development Programme Ethiopia. (2017). National logistics strategy.

Viale, E. (2017). El extractivismo urbano [Urban extractivism]. In A. M. Vásquez Duplat (Ed.), Extractivismo urbano [Urban extractivism] (pp. 15-20). El Colectivo.

Vialidad Nacional. (n.d.). Circunvalación transito pesado $y$ accesos a puertos [Heavy traffic bypasses and port accesses]. Unpublished document.

Weldesilassie, A. B., Gebreeyesus, M., Abebe, G., \& Aseffa, B. (2017). Study on industrial park development: Issues, practices and lessons for Ethiopia (Research Report No. 29). Ethiopian Development Research Institute.

Werner, M. (2016). Global production networks and uneven development: Exploring geographies of devaluation, disinvestment, and exclusion. Geography Compass, 10(11), 457-469.

Whitfield, L., Staritz, C., \& Morris, M. (2020). Global value chains, industrial policy and economic upgrading in Ethiopia's apparel sector. Development and Change, 51(4), 1018-1043.

Wiig, A., \& Silver, J. (2019). Turbulent presents, pre- 
carious futures: Urbanization and the deployment of global infrastructure. Regional Studies, 53(6), 912-923.

World Bank. (2017). Ethiopia trade logistics project. Combined project information documents/integrated safeguard data sheet. Appraisal stage (Report No. PIDISDSA19897).

Zhang, X., Tezera, D., Zou, C., Wang, Z., Zhao, J., \& Gebre- menfas, E. A. (2018). Industrial park development in Ethiopia. Case study report (Research and Statistics Working Paper, No. 21/2018). UNIDO Department of Policy.

Ziso, E. (2017). A post state-centric analysis of ChinaAfrica relations: Internationalisation of Chinese capital and state-society relations in Ethiopia. Springer.

\section{About the Authors}

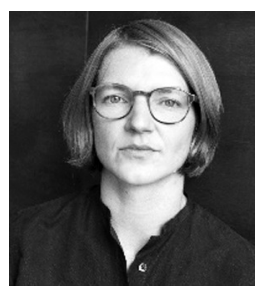

Elke Beyer is an urban researcher and currently visiting professor at the Habitat Unit, in the Institute of Architecture, at Technical University of Berlin. She taught theory and history of architecture at TU Berlin and ETH Zurich, where she also completed her PhD. She was a research associate in the project "Shrinking Cities," Berlin, and at the Leibniz Institute for Research on Society and Space, Erkner. Her research fields include transnational production spaces, architecture, and planning of the post-WW2 era in Europe, and global knowledge transfer in architecture and urbanism.

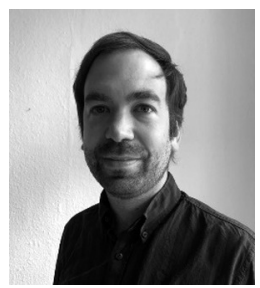

Lucas-Andrés Elsner is an urban planner and geographer educated at Technical University of Berlin and University of Münster. Since 2018 he is based at the Habitat Unit, Institute of Architecture, Technical University of Berlin, where he is currently working on a joint project with the University of the Witwatersrand (Johannesburg, South Africa) and the University of Lagos (Nigeria) on graduate education in urban disciplines in sub-Saharan Africa. His research focuses on the relationship between uneven spatial development, transport infrastructures, and global production relations.

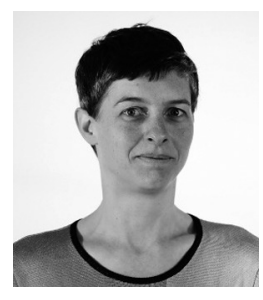

Anke Hagemann is interim professor for International Urbanism and Design at the Institute for Architecture, Technische Universität Berlin. She graduated in architecture, co-founded the journal An Architektur, worked as a research associate in the project "Shrinking Cities," and taught at various universities (ETH Zurich, HCU Hamburg, University of Stuttgart, TU Berlin). In 2020-2021, she was interim professor of Urban Planning at BTU Cottbus-Senftenberg (Germany). Her research fields include urban mega-events, unplanned urban transformation, global commodity flows, and transnational production spaces.

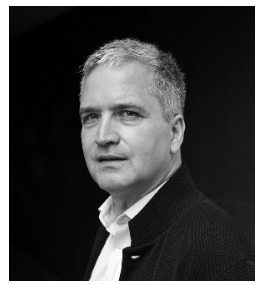

Philipp Misselwitz is an architect and urban researcher based in Berlin. He studied at the University of Cambridge and the Architectural Association London. In 2013, he was appointed Chair of the Habitat Unit-Department of International Urbanism and Design at the Technical University of Berlin. In various research, teaching, and consulting projects, he addresses the impact of global sustainability challenges on urbanisation and the changing role of architects and planners. Since 2017 he is a visiting professor at the University of the Witwatersrand (Johannesburg, South Africa). 